\title{
External and internal triggers of cell death in yeast
}

\author{
Claudio Falcone $^{1} \cdot$ Cristina Mazzoni $^{1}$
}

Received: 14 March 2016/Accepted: 18 March 2016/Published online: 5 April 2016

(C) The Author(s) 2016. This article is published with open access at Springerlink.com

\begin{abstract}
In recent years, yeast was confirmed as a useful eukaryotic model system to decipher the complex mechanisms and networks occurring in higher eukaryotes, particularly in mammalian cells, in physiological as well in pathological conditions. This article focuses attention on the contribution of yeast in the study of a very complex scenario, because of the number and interconnection of pathways, represented by cell death. Yeast, although it is a unicellular organism, possesses the basal machinery of different kinds of cell death occurring in higher eukaryotes, i.e., apoptosis, regulated necrosis and autophagy. Here we report the current knowledge concerning the yeast ortho$\operatorname{logs}$ of main mammalian cell death regulators and executors, the role of organelles and compartments, and the cellular phenotypes observed in the different forms of cell death in response to external and internal triggers. Thanks to the ease of genetic manipulation of this microorganism, yeast strains expressing human genes that promote or counteract cell death, onset of tumors and neurodegenerative diseases have been constructed. The effects on yeast cells of some of these genes are also presented.
\end{abstract}

Keywords Yeast - Apoptosis - Caspase · Autophagy · Necrosis

Cristina Mazzoni

cristina.mazzoni@uniroma1.it

Claudio Falcone

Claudio.falcone@uniroma1.it

1 Pasteur Institute-Cenci Bolognetti Foundation; Department of Biology and Biotechnology "Charles Darwin", Sapienza University of Rome, Piazzale Aldo Moro 5, 00185 Rome, Italy

\section{Introduction}

Regulated cell death (RCD) can be executed through distinct subroutines, sometime partially overlapping, leading to apoptosis, autophagy and programmed necrosis [1], and such scenarios have been described also in yeast cells under physiological or induced stress conditions.

In mammals, RCD can be observed during aging or in consequence of pathologies including neurodegenerative disorders, hypoxia and heart strokes. In the opposite direction, loss of RCD can result in the onset of cancer.

Due to its simple handling, yeast represents a very useful eukaryotic model system for deciphering the complex network of the different and often interwoven RCD pathways occurring in mammals, aiming, in particular, to the identification of executors, to the role of cellular organelles and compartments, and to the detection of new cell phenotypes in response to external and internal triggers.

\section{Apoptotic cell death}

Yeast apoptosis was first described in cells carrying a mutated $C D C 48$ gene ( $\operatorname{cdc} 48^{\mathrm{S} 565 \mathrm{G}}$ ), which codes for the AAA-ATPase and has roles in cell division, ubiquitin-dependent ER-associated protein degradation (ERAD) and vesicle trafficking [2]. Later on, it was found that mutations in the VCP gene, the metazoan homolog of the yeast $C D C 48$, gave rise to apoptotic phenotypes in mammalian cell cultures [3, 4], in trypanosomes [5], in Drosophila [6] and in zebrafish [7]. Like mammalian cells, yeast cells undergoing apoptosis display characteristic markers such as DNA breakage, chromatin condensation, phosphatidylserine externalization, reactive oxygen species 
(ROS) accumulation and cytochrome $c$ release from mitochondria. In nature, this process might favor the elimination from the yeast population of old and/or unhealthy cells, increasing the availability of nutrients for young and healthy cells [8].

In this organism, apoptosis is induced by internal and external triggers including cellular dysfunctions, $\mathrm{H}_{2} \mathrm{O}_{2}$, acetic acid and many others $[9,10]$. Although lacking Bax and $\mathrm{Bcl}$ genes, several yeast orthologs of mammals' main apoptotic regulators, such as AIFl (AIF), NUCl (EndgoG), MCA1/YCA1 (metacaspase), NDI1 (AMID), NMA111 (HtrA2/Omi) and others, have been identified, demonstrating that the basal apoptotic machinery is present in this unicellular organism [11].

\section{Necrotic cell death}

Necrosis in mammals is a physiological cellular process that becomes more evident in some disorders and after virus and bacterial infection. In contrast to apoptosis, necrotic cells release intracellular contents following the plasma membrane rupture. In yeast cells, $\mathrm{H}_{2} \mathrm{O}_{2}$, acetic acid and heavy metals, well-known triggers of apoptosis at low doses, can also induce accidental necrosis at higher concentration because of the excessive damage to cellular components $[9,10,12]$.

Yeast cells also posses a programmed necrotic pathway under conditions similar to those regulating programmed necrosis in mammals [1]. Necrosis in yeast is positively regulated by aging, low $\mathrm{pH}$ and mitochondria while inhibited by spermidine, EndoG, vacuolar and peroxisomal functions [13]. Homologs of known mammalian mediators of necrosis have been found in the Saccharomyces cerevisiae genome but additional studies are still needed to identify the executors and clarify a putative altruistic meaning of necrotic cell death in unicellular yeasts. Liponecrosis has been recently reported as an additional cell death module of RCD in yeast cells exposed to exogenous palmitoleic acid (POA) [14]. Cells undergoing liponecrosis do not show hallmarks of apoptosis nor plasma membrane rupture observed in necrosis and exhibit, as in autophagic cell death, a non-selective degradation of cellular organelles but not increased cytoplasmic vacuolization. Peroxisomal fatty acid oxidation acts as a pro-survival process in that protects yeast cells from liponecrotic death by reducing the cellular level of POA [14]. Deletion of ATG32, the gene encoding a mitochondrial outer membrane protein required to initiate mitophagy, results in increased sensitivity to death triggered by POA, pointing to macromitophagy as an opponent of POA-induced cell death. Interestingly, the absence of the serine/ threonine kinase Atg1p, which is required for the execution of macroautophagy, while lowering clonogenic survival of yeast cells submitted to apoptosis by $\mathrm{H}_{2} \mathrm{O}_{2}$, reduces the lethality induced by POA [14]. Moreover, while Nuc1p, Aiflp and Nma111p are not involved in POA response, the absence of the metacaspase Mcalp enhances POA-induced cell death, suggesting a pro-survival role of this apoptotic regulator [15].

These results altogether reinforce the idea that POAtriggered death is in fact an additional new form of RCD.

\section{Autophagy and cell death}

Macroautophagy is a conserved process required for the degradation and recycling of cytoplasmic components by delivering molecules and entire organelles to the vacuole or to lysosomes, depending on the eukaryotic cell type. The morphological hallmark of autophagy is the formation of the autophagosome, a vesicle bounded by a double membrane, within which cytoplasmic components remain randomly (non-selective autophagy) or selectively (selective autophagy) sequestered. Selective autophagy ensures the health of cells by removing protein aggregates and carrying the turn-over of mitochondria (mitophagy), peroxisomes (pexophagy), lipids (lipophagy), and ER (ERphagy), which might represent potential triggers of apoptosis. After fusion with the vacuole, the material is degraded to simpler molecules, which are then released again into the cytoplasm for reuse. Autophagy, as well selective autophagy [16], occurs in yeast cells at basal level and is up-regulated by nutritional changes and starvation. The regulation of the process determines the size and number of autophagosomes under normal and inducing conditions. Studies with yeast allowed the identification of more than 30 autophagy-related (Atg) proteins, most of which are conserved in higher eukaryotes. In the presence of nutrients, most of ATG genes are repressed at transcriptional level in consequence of the inhibition of activators and/or activation of repressors of autophagy [17]. In several organisms, under specific conditions, autophagy mediates a particular type of RCD, defined as autophagic cell death [18]. In yeast, relationships between autophagy and cell death are still to be explored, and some evidences suggest that autophagy may accelerate cell death in $S$. cerevisiae following the expression of human p53, BAX and under starvation conditions [19-21].

\section{Yeast cell death regulators}

One of the first genes involved in yeast RCD was MCAl/ $Y C A 1$, which codes for a protein showing a caspase activity and plays an important role in regulating apoptosis in yeast 
[22]. Mcalp has been classified as a type I metacaspase, found also in many other organisms, with a characteristic $\mathrm{N}$-terminal pro-domain that is thought to be cleaved off upon activation [23]. The autocatalytic processing of Mcalp requires $\mathrm{Ca}^{2+}$ ions and the crystal structure of the protein revealed a canonical caspase-like fold and it can exist as a monomer in both solution and crystals [24]. While caspases cleave substrates after an aspartate residue, metacaspases cleave after arginine or lysine and the identification of their substrates is poorly known [25]. Concerning the Mcalp substrates, so far only the glycolytic enzyme GAPDH (glyceraldehyde 3-phosphate dehydrogenase) has been identified as a possible target, although the physiological relevance and effects of this cleaved protein remain to be elucidated [26]. Mcalp has also been shown to be involved in protein quality control (PQC) displaying some pro-survival functions, which suggest a dual role of this protein acting in both pro-death and pro-survival pathways [27-29]. As an example, although an increased caspase activity was detected in the $c d c 48^{5565 G}$ mutant [30], from a synthetic genetic array (SGA) analysis it was found that a $c d c 48$ conditional mutant negatively interacted with the mcal null mutant, suggesting that Mcalp can buffer the absence of Cdc48p [27]. It has been estimated that about $40 \%$ of cell death in yeast is Mcalp dependent, suggesting the presence of many alternative cell death pathways. Beside Mcalp, there are other proteases involved in yeast PCD. The caspase-like protease Esp1p, upon $\mathrm{H}_{2} \mathrm{O}_{2}$ cell exposure, cleaves cohesin $\operatorname{Mcd} 1 / \operatorname{Rad} 21$. The truncated C-terminal fragment of Mcd1p translocates from the nucleus to mitochondria, causing the decrease of mitochondrial membrane potential and the release of cytochrome $c$ [31]. Moreover, the protease activity Kex1p plays a role in promoting yeast PCD in wbpl-1 N-glycosylation mutants, during chronological aging, following tunicamycin and acetic acid treatments [32].

Apoptosis-inducing factor (AIF1), homologue to mammalian AIF, is a mitochondrially localized protein that, upon apoptotic insults, translocates to the nucleus where it mediates chromatin condensation and DNA degradation [33]. As its mammalian counterpart, AIF1 DNA degradation activity requires cyclophilin A and plays a vital role in maintaining mitochondrial activity $[34,35]$. NDI1, which codes for the inner mitochondrial membrane NADH dehydrogenase and catalyzes the oxidation of intramitochondrial NADH, is the human homologue of the AIFhomologous mitochondrion-associated inducer of cell death (AMID). In facts, NDII overexpression causes cell death while its deletion lowers ROS production and extends CLS [36]. Similar effects, although to a lower extent, were observed for Nde1p, the protein localized on the outer mitochondrial membrane and responsible for oxidation of cytosolic NADH [36].
$N U C 1$, the yeast ortholog of mammalian endonuclease $\mathrm{G}$ (EndoG), is another cell death effector that translocates from mitochondria to nucleus upon apoptosis induction [37]. Nuc1p pro-apoptotic activity requires karyopherin Kap123p, homologue to the mammalian mitochondrial permeability transition pore (MPTP), and H2B phosphorylation.

The absence of $N U C 1$ protects yeast from cell death only in respiratory conditions while, in fermentative conditions, it enhances necrotic cell death [37]. EndoG has a vital role in both yeast and mammalian cells in maintaining polyploidy cells [38]. Nma111p (nuclear mediator of apoptosis) is a yeast serine protease, homologous to the mammalian pro-apoptotic protein mitochondrial-located HtrA2/Omi that, differently from the latter, it resides in the nucleus. Deletion or overexpression of NMA111 causes protection or induction of cell death, respectively [39].

Bir1p, the target of the Nma111p activity, acts as an inhibitor of apoptosis (IAP) in yeast [40].

Pep4p, a pepsin-like aspartic protease ortholog of human Cathepsin (CatD), translocates from the vacuole to the cytosol and is involved in the degradation of nucleoporins following $\mathrm{H}_{2} \mathrm{O}_{2}$-induced apoptosis [41]. Yeast pep4 mutant strains undergo both apoptosis and necrosis during chronological aging.

The proteolytic activity of Pep4p is required to contrast apoptotic cell death while the non-proteolytic part of this protein is involved in its anti-necrotic function [13]. In addition Pep4p, as well as CatD, shows a protective role in acetate-induced apoptosis in both yeast and colorectal cancer (CRC) cells [42, 43] depending on its proteolytic capacity. In mammalian cells, BH3-only proteins upon induction of apoptosis are targeted to mitochondria where they induce mitochondrial outer membrane permeabilization (MOMP), thereby initiating the regulated disintegration of the cell $[44,45]$. The presence of a BH3-only protein encoded by the $Y N L 305 c$ gene has been reported in yeast, later renamed $Y B H 3$. Overexpression of Ybh3p sensitizes yeast to apoptotic stimuli, while its absence protects cells against $\mathrm{H}_{2} \mathrm{O}_{2}$, acetic acid, murine BAX expression and extends both replicative and chronological lifespan. Ybh3p-mediated cell death is independent of Mcalp, Aif1p, Nma111p and Nuc1p, suggesting that Ybh3p triggers its own mitochondrial cell death pathway [46]. The same gene, named BXII (for Bax inhibitor) in this occasion, has been reported to be involved in unfolded protein response (UPR) and to play a protective role in heat shock response, ethanol and glucose induced cell death [47]. The opposite pro- and anti-apoptotic role of this protein might depend on the apoptosis-inducing conditions applied. 


\section{Internal triggers}

Alterations of fundamental cellular pathways, such as DNA replication, actin cytoskeleton, mRNA stability and protein modifications and degradation, produce triggers that induce various forms of yeast cell death [48-53].

Some forms of cell death require the activity of the metacaspase encoded by the MCAl gene [22]. Differently, other forms of PCD are independent of Mcalp and follow alternative pathways. Yeast cell death can also be induced by expressing heterologous genes involved in apoptosis, tumor suppression and neurodegenerative diseases.

\section{Reactive oxygen species (ROS)}

Yeast cells accumulating ROS show morphological markers peculiar for apoptosis in mammals. The phenomenon is caspase dependent in that, in the absence of the metacaspase Mca1p, apoptosis is prevented [22].

ROS in yeast are mainly produced within mitochondria [54] during aerobic respiration as a result of the leakage of electrons from the respiratory chain, which react with oxygen. When ROS concentration exceeds normal antioxidant defenses, yeast cells respond with the activation of transcription factors, namely Yap1p, Skn7p, Msn2p, and Msn4p that, in turn, regulate transcription of genes involved in antioxidant defenses [55, 56]. ROS accumulation is the cause of oxidative damaging of nucleic acids, proteins and lipids and, depending on concentration, can induce apoptosis as well necrosis in different cells. ROS-induced cell death has been put in relation with aging, neurodegenerative diseases and cancer and many articles have focused on oxidative stress also in yeast $[55,57]$.

\section{Aging}

Replicative life span (RLS) and chronological life span (CLS) are two models of aging in yeast cells. RLS refers to the number of divisions of an individual cell before budding arrest while CLS represents the time a culture maintains viability during stationary phase. In both cases, cell death eliminates old and damaged cells and is accompanied by typical markers of apoptosis [58-60]. Nevertheless, the mechanisms underlying the two forms of cell death are only partially overlapping. As an example, the deletion of the metacaspase gene MCAl prevents apoptotic cell death during CLS while, in contrast, reduces the numbers of cell divisions in RLS [27, 59]. During CLS, in addition to apoptosis, yeast cells die also through programmed necrosis [11].

\section{DNA replication and RNA stability}

Initiation of DNA replication is a conserved process that requires the origin recognition complex $(O R C)$, constituted by a six-subunit complex of proteins [61]. ORC2 codes for a subunit of the ORC complex and orc2-1 ts mutant cells, at non-permissive temperature, show defects in initiation of DNA replication, activate DNA damage responses, premature aging and undergo apoptosis following the Mcalpdependent pathway [53, 62].

An important component of the pre-replicative complex required for the initiation of eukaryotic DNA replication is Cdc6p, which is rapidly degraded in a proteasome-dependent way in cells undergoing apoptosis induced by the DNA-damaging drug adozelesin [63].

The steady-state level of mRNAs is another fundamental cellular process, which depends on the equilibrium between mRNA synthesis and decay [64]. Mutants in decapping, a crucial event of mRNA degradation, such as $d c p 1, d c p 2, d h h 1, l s m 1-7$, show apoptotic phenotypes and accelerated chronological aging [51, 65]. At least in one of these mutants (Kllsm4 41 ), apoptotic death was demonstrated to be Mcalp dependent [66], and most of the apoptotic phenotypes were suppressed by the overexpression of HIRl, PGKl and NEMI, the genes encoding a subunit of the HIR complex involved in histone gene transcription, the phosphoglycerate kinase and the catalytic subunit of Nem1p-Spo7p phosphatase holoenzyme that regulates Pah1p (lipin) activity, respectively, [67-69]. This suggests a link between cell death induced by defects in RNA degradation and histone expression, ATP production and phospholipid homeostasis.

Metacaspase-dependent apoptotic cell death has been recently reported in strains defective in cytoplasmic exosome function (ski2A mutants) or deadenylation (ccr4 $\Delta$ pan $2 \Delta$ mutants) pointing to mRNA degradation as a relevant pathway involved in yeast cell death [70].

In mammalian cells undergoing classical apoptosis, $3^{\prime}$ truncated mRNA decay intermediates with uridylate-rich tails are generated, which have been suggested to represent an early apoptotic phenotype [71, 72].

Although uridylyl transferase has not been described in budding yeast [73], the accumulation of capped mRNAs in decapping mutants could represent for yeast cells an internal apoptotic signal whose molecular mechanisms still need a deeper investigation.

Apoptotic stimuli in yeast also induce endonucleolytic degradation of rRNA, more evident in fermenting cells, which is dependent on histone H2B modifications and independent of Mcalp and Aif1p [74]. Upon oxidative stress, also cytoplasmic tRNAs are degraded by the release from the vacuole of the Rnylp RNase; although little is 
know about the cell death-induced pathway, overexpression of $R N Y 1$ exacerbates the birl and yapl growth defect [75]. Altogether, these results clearly point to crosstalk between RNA metabolism and RCD.

\section{Epigenetic modifications}

Histone modifications, besides their regulative role in a variety of cellular processes such as gene transcription, DNA repair, mitosis, meiosis, and development, have been also associated to the establishment of cell death in both mammalian and yeast cells [76].

In yeast, H2B-K11 deacetylation, operated by the histone deacetylase (HDAC) Hos3p, is necessary to allow the phosphorylation of the apoptotic mark H2B-S10 (H2B-S16 in human) by Ste20p kinase, the yeast homolog of mammalian Mst1 kinase [77, 78]. Since H2B-S10 phosphorylation is also present during meiosis, it has been proposed that this modification is associated to large-scale changes in chromatin structure. [79].

Histone H2B ubiquitination is required for nucleosome stability and its loss, in the E3 ubiquitin-ligase brel and ubiquitin protease $u b p 10$ mutants, sensitizes metacaspasedependent cell death [80, 81].

$\mathrm{H} 2 \mathrm{~B}$ ubiquitination is a prerequisite for histone $\mathrm{H} 3 \mathrm{~K} 4$ and H3K79 methylation and it was recently reported that loss of $\mathrm{H} 3 \mathrm{~K} 4$ methylation, due to the inactivation of the methyltransferase Set1p, triggers apoptotic cell death partially dependent on Mcalp during chronological aging and on EndoG/Nuc1p after hydrogen peroxide treatment [82].

\section{Death in aging colonies}

In liquid media, yeast population develops in the form of single cells that replicate several times and finally die through the apoptotic process. During growth on solid media, both in nature and in laboratories, cells remain in contact giving rise to colonies that enlarge over time. In this case, apoptotic death occurs in oldest cells, located in the middle of the colony, through a Mcalp or Aif1p-independent pathway in response to an ammonia signal emitted by aged surrounding colonies. Nevertheless, D2R staining of cells from colonies of the mcal mutant, indicated the presence of Asp-ase or another caspase-like activity [83].

\section{Heterologous expression of cell death genes}

Expression in yeast of the human key apoptotic inducer Bax leads to apoptotic cell death accompanied by cytochrome $c$ release. These events can be reverted by the contemporary heterologous expression of Bcl-2 or Bcl-xL, as well of 14-3-3 $\beta / \alpha$ and human LDH [84-86].
Yeast models expressing neurotoxic proteins have been recently reviewed [87].

Expression in yeast of $\alpha$-synuclein, an intracellular trigger of Parkinson's disease, results in apoptosis as well as necrosis, which are modulated by the activities of the ubiquitin-proteasome system (UPS), autophagy, and ubiquitin-dependent vesicular trafficking [87-89]. Moreover, alpha-synuclein toxicity depends on chronological aging, functional mitochondria and it requires the presence of Nuc1p [90].

Expanded poly-glutamine (poly-Q) domains cause protein aggregation and neurodegeneration [91, 92]. Although the yeast genome does not contain an ortholog of the human gene htt, responsible for Huntington disease (HD), expression of Htt103Q in yeast leads to widespread cellular dysfunction resulting in death with apoptotic markers [92]. Poly-Q aggregates induce ER stress, mitochondrial dysfunction and impair vesicle-based protein degradation, including autophagy [87].

The spinocerebellar ataxia type-3 (SCA3) is another disease caused by the expansion of poly-Q in the gene atxn3, which encodes a protein known as ataxin-3 (AT3) [93]. The expression of AT3 in yeast is toxic and leads to accumulation of ROS, imbalance of the antioxidant defense system, loss in cell membrane integrity and necrotic cell death, without the induction of apoptosis [94].

Expression in yeast of a mutated form of DFNA5, a gene responsible for autosomal dominant hearing loss (HL), induces ROS accumulation leading to a caspase-independent cell death that relies on mitochondrial functions such as the mitochondrial fission protein Fis1p, the voltagedependent anion channel Porlp, and the mitochondrial adenine nucleotide translocators Aac1p and Aac3p [95]. More recently, it has been reported that ER and protein folding are also involved in RCD caused by DFNA5 both in yeast and in HEK293T cells [96]. It has also been reported that the heterologous expression of human immunodeficiency virus (HIV-1) protease [97] and the proteinaceous elicitor harpin (Pss) from Pseudomonas syringae [98] led to regulated necrosis in budding yeast.

Yeast has also been used as a model for the study of tumors, also because of similarities in carbon metabolism with cancer cells. The p53 tumor suppressor protein is a nuclear phosphoprotein that plays a key role in safeguarding genome integrity [99]. Mutations in the p53 gene are found in $45 \%$ of human cancers cells that, in consequence, undergo uncontrolled cell proliferation and often acquire resistance to chemotherapy [99]. S. cerevisiae does not contain p53 homologues and, in this respect, it can be considered a powerful 'clean room' model to study the different molecular pathways associated with the presence of this protein. Mammalian p53 can function as a transcription factor in yeast [100] and several groups used 
yeast for studying the transcriptional activity of human wild-type and tumor-derived p53 mutated proteins [101]. More recent studies have shown that the expression of $\mathrm{p} 53$ induces apoptosis-like cell death making p53, after Bax, the second heterologous pro-apoptotic gene, and strengthening the idea that the apoptotic processes are conserved throughout the evolution [102, 103]. Cell death induced by p53 expression in yeast is Mcalp independent and mainly mediated by Nuc1p, suggesting the importance of yeast mitochondria in p53-induced cell death [104, 105]. Very recent studies have shown that the expression of p53 family proteins in yeast causes growth inhibition, increased actin expression and actin depolarization, ROS production and an autophagic cell death [21]. The expression in yeast of the well-known breast tumor suppressor genes BRCA1 and BRCA2 suggested a role of these genes in the maintenance of genomic stability and resulted in pleiotropic phenotype, such as the inhibition of cell growth and the formation of small colonies [101]. More recently, it has been reported that BRCA2 expression sensitizes yeast cells to acetic acidinduced programmed cell death [106].

\section{External triggers}

Many external triggers have been shown to induce apoptosis in budding yeast including hydrogen peroxide, acetic acid, ethanol, high salt, osmotic stress, lipids, UV irradiation, heat stress, and numerous heavy metal ions [11].

\section{Acetic acid-induced cell death}

A detailed description of the cellular events accompanying yeast cell death during exposure to acetic acid has been recently reported [107]. Acetic acid is one of the main subproducts, which accumulate in the culture medium during yeast alcoholic fermentation. Although $S$. cerevisiae can utilize acetate as carbon source, high concentration of acetic acid induces cell death (referred as AA-PCD) accompanied by all apoptotic hallmarks. In yeast, as in mammalian cells, mitochondria play a primary role in AAPCD. In the course of exposure to acetic acid, yeast cells show mitochondrial swelling [108], membrane depolarization, ROS production, reduction of cytochrome oxidase activity and mitochondrial outer membrane permeabilization (MOMP), accompanied by release of cytochrome $c$ and Aif1p [33, 109, 110]. The ROS scavenger $\mathrm{N}$-acetylcysteine (NAC) prevents AA-PCD in wild-type cells while not in cells lacking Ycalp and cytochrome $c$. In these mutants, acetic acid can still induce cell death, although at lower rate compared to the respective wild-type strains, suggesting the existence of Ycalp and ROS-independent pathways [111, 112].
The partial prevention of AA-PCD by disrupting cytochrome $c$ could be in relation with the increased mitochondrial membrane potential and with the lack of cytochrome $c$ oxidase activity. According to this, respiratory deficient cells lacking mitochondrial DNA ( $\rho^{0}$ cells) display resistance to acetic acid-induced death [110]. AAPCD is regulated by a number of proteins including Porlp (yeast voltage-dependent anion channel), which plays a protective role, and ADP/ATP carrier proteins, which are required for mitochondrial outer membrane permeabilization and cytochrome $c$ release [113]. Other factors involved in some way in AA-PCD execution are Fis1p, Dnm1p and Mdv1p, the mitochondrial proteins responsible for fission and fusion events of these organelles, [114], and Pep4p, the yeast homologue of cathepsin $\mathrm{D}$, which plays an important role for degradation of mitochondria in AA-PCD [43, 110]. Recently, it has been reported that components of the MAPK pathways modulate acetic acid-induced cell death. In fact, mutants in components of the mating pheromone response, as well in components of the high osmolarity glycerol (HOG) and the cell wall integrity (CWI) pathways are significantly more resistant to AA-PCD.

In addition, cytochrome $c$ release from mitochondria was not detected in acetic acid-treated $b c k 1 \Delta$ or $\operatorname{sit} 2 \Delta$ mutants, indicating that the CWI pathway mediates acetic acid-induced apoptosis through a mitochondrial pathway [115].

It has been recently reported a proteomic study during AA-PCD in both wt and mcal null mutants indicating that in the absence of Ycalp cell death is induced through the activation of ceramides, whereas in the presence of the gene yeast cells underwent an AA-PCD pathway characterized by the shift of the main glycolytic pathway to the pentose phosphate pathway and by a proteolytic mechanism to cope with oxidative stress [116].

\section{Hyperosmotic stress}

Hyperosmotic stress, an additional external trigger of cell death observed in mammalian cells, induces apoptosis in several pathological states such as diabetes, inflammatory bowel disease and hypernatremia [117]. Yeast can grow by fermentation in media containing up to $40 \%$ glucose [118], a nutrient-rich but dangerous situation in that high osmolarity induces water efflux, cytosolic ions concentration and cell shrinkage. Following hyperosmotic stress, yeast activates adaptive responses that are mainly regulated by the high osmolarity glycerol (HOG) pathway, evolutionary conserved up to humans [119]. It has been reported that $S$. cerevisiae cells exposed to hyperosmotic stress in the presence of high glucose or sorbitol concentrations increase ROS production and show all peculiar apoptotic markers that require the involvement of mitochondria and 
of a partially $c y t$-dependent Mcalp activation [120]. It has also been reported that high salinity, as high $\mathrm{NaCl}$ concentrations, induces in yeast apoptotic cell death [121] that follows Mcalp-dependent pathway in wild-type strains, while Mca1p-independent pathways in sro7/sro77 double mutants [122].

\section{Killer toxin}

The "killer phenomenon" is widespread in different yeasts and consists of the secretion of protein toxins by killer strains that kill sensitive cells. Depending on the toxin nature, the killing mechanism is different in that some toxins act as ionophores disrupting the cytoplasmic membrane while others enter sensitive cells by receptormediated endocytosis, block DNA synthesis and arrest cell cycle in G1/S phase [123].

At low toxin concentrations, which are closer to the natural environmental situation, killer toxins, whatever the mode of cell killing, induce ROS production and Mca1pdependent apoptotic cell death. In contrast, yeast cells exposed to high toxin undergo necrotic cell death [124].

\section{Pheromone-induced cell death}

Yeast pheromones are short peptides secreted by cells of opposite mating types required for mating.

Pheromones, after binding to a $G$ protein-coupled receptor (Ste2p or Ste3p), activate a specific MAP kinase signaling pathway allowing the induction of mating genes. The main component of the mating pathway is kinase Ste 20 p, the deletion of which prevents pheromone-induced death and the formation of ROS [125]. Pheromone-induced apoptosis takes place in consequence of increased intracellular $\mathrm{Ca}^{2+}$, ROS generation, formation of the permeability transition pore, Ysp1p-dependent mitochondrial fragmentation and release of cytochrome $c[125,126]$.

When cells are exposed to elevated concentrations of pheromone, as well after failure of mating, cell death seems to occur without showing certain peculiar apoptotic markers in a metacaspase-independent way, suggesting the activation of necrosis-like pathways [31]. This could represent an altruistic kind of death for the elimination of infertile or damaged haploid cells from the yeast community $[11,125]$.

\section{Effect of drugs on yeast cell death}

The availability of gene deletion collection, together with the advancing development of yeast-based functional genomic and proteomic technologies, supports the utility of $S$. cerevisiae as a model organism in the drug-discovery process [127]. Due to the high conservation of basic cellular processes present in higher organisms, yeast is also a powerful system for the study of the mechanism of PCDinducing drugs, since it is known that most of anticancer compounds induce apoptotic cell death.

Among antitumor drugs, the apoptotic phenotypes induced in yeast cells following paclitaxel, arsenic, bleomycin and valproate treatment, as well their mechanism of action, have been studied in detail. In the case of inhibitors of topoisomerases and/or cell cycle progression, there is not sufficient evidence for their role as RCD inducers, although many of them stimulate ROS production [128].

Some bioisosteres of arylthioindoles, which are potent tubulin assembly inhibitors, arrest growth of yeast and MCF-7 human breast carcinoma cells. Interestingly, the inhibition of tubulin polymerization in yeast triggers apoptosis mainly through MCAl and EndoG [129, 130].

Free fatty acids, in dependency on the degree of unsaturation, as well as ceramide, stimulate yeast cells to undergo regulated necrosis, [131]. Due to its sensitivity to most of antifungal drugs, yeast is used for the search and characterization of new compounds with lower toxicity against human pathogens. Molecules of different origins and mode of action, such as amphotericin B, osmotin, dermaseptin, pradimicin and histatin, exert their antifungal activity primarily through induction of apoptosis in Saccharomyces cerevisiae and/or Candida albicans [128].

The yeast model system can be applied also to study the beneficial effects of a range of molecules and nutrients on cells and large-scale search for anti-apoptotic molecules has been performed by the use of fzol yeast mutants, which are impaired in mitochondrial fusion [132]. Some compounds such as acetyl-L-carnitine (ALC), used as therapeutic for stroke, myocardial infarction and neurodegenerative diseases, prolongs yeast lifespan in the presence of Mca1p, functional mitochondria and counteracts apoptosis [133]. Ascorbic acid, beta-carotene and caffeic acid, contained in some nutrients, are known antioxidants that reduce accumulation of ROS-protecting cells from aging and $\mathrm{H}_{2} \mathrm{O}_{2}$-induced cell death [134]. Apple's extracts, rich in ascorbic acid and polyphenols are known to act as antitumors and prevent ROS accumulation, aging and cell death in yeast cells [135]. Resveratrol is a natural polyphenol, present especially in grapes, red wine and berries, showing antiaging and potential cardioprotective effects. This compound is also a potent inducer of autophagy through the activation of deacetylase SIRT1 in humans, as well of its ortholog SIR2 in yeast. Spermidine, a polyamine found in citrus fruit and soybean, is an acetylase inhibitor and also an inducer of autophagy independent of human SIRT1 and yeast SIR2 genes. It has been reported that both compounds induce autophagy by distinct pathways converging on the acetylproteome [136]. In yeast, deacetylation of histone $\mathrm{H} 3$ by spermidine reduces ROS 
levels produced during aging and has an anti-necrotic role promoting cell survival through the induction of autophagy [137].

\section{Organelles}

\section{Mitochondria}

Mitochondria play a central role in cellular functions including energy production, iron-sulfur biogenesis, calcium homeostasis, and RCD in eukaryotes. Most of the mitochondrial functions depend on the maintenance of tubular network deriving from the equilibrium between fusion and fission events. Mitochondrial fragmentation into punctuate structures is a common early feature of apoptosis in both mammalian and yeast cells [108, 138]. Apoptotic signals determine the release from the mitochondria of pro-apoptotic proteins such as cytochrome $c$, AIF1, EndoG and Omi/HtrA2 [138]. The release of cytochrome $c$ from mitochondria, one of the signals triggering cell death, was firstly demonstrated in cells expressing the human pro-apoptotic protein Bax [139]. $A A C 1 / 2 / 3$ and PORI are the yeast orthologs of mammalian adenine nucleotide translocase (ANT) and voltagedependent anion channel protein (VDAC), respectively. Their role in the release of cytochrome $c$ during Baxinduced cell death is controversial, depending on the experimental conditions [140-142]. The absence of ADP/ ATP carrier (AAC) proteins, encoded by AAC $1 / 2 / 3$, protected cells exposed to acetic acid and diamide but not to $\mathrm{H}_{2} \mathrm{O}_{2}$, while deletion of PORI enhances apoptosis triggered by all these compounds [113].

The overexpression of the human gene VDAC1 induces the accumulation of ROS and is toxic for yeast cells growing on respiratory carbon sources but not on glucose [143]. This could be explained by the increase within cell population of respiratory deficient mutants, which are known to show extended lifespan [66, 144]. The machinery responsible for mitochondrial fission in healthy yeast cells was identified as a complex of three proteins, Dnm1p, Mdv1p/Net2p, and Fis1p [145]. Dnm1p has been shown to promote mitochondrial fission and cell death following exposure to environmental stress while its deletion protects cells from death and aging [114, 146, 147].

Other proteins, involved in mitochondrial functions, protect cells from death. As an example, the absence of Cit1p, the major mitochondrial citrate synthase, or Isc1p, the inositolphosphosphingolipid phospholipase $\mathrm{C}$, results in oxidative stress hypersensitivity associated with apoptotic markers that were suppressed by the contemporary absence of the Mcalp metacaspase [29, 148].

\section{Peroxisomes}

Among cellular organelles, peroxisomes perform fundamental metabolic pathways such as $\beta$-oxidation of fatty acids and hydrogen peroxide detoxification.

Peroxisomes are ubiquitous in eukaryotes varying in shape, size and number adapting to cellular requirements. Like mitochondria, peroxisomes increase in their number by a fission mechanism, which in yeast requires Dnm1p or Vps1p, and it has been recently reported that the inhibition of peroxisome fission increases yeast chronological lifespan [149].

Together with mitochondria, peroxisomes are the main source of reactive oxygen species that accelerate aging and cell death, but their role in these processes still requires elucidation. Peroxisomes are involved in regulation of yeast necrosis. In fact, it has been reported that the deletion of PEX6, the gene encoding a protein involved in peroxisomal protein import, results in increased ROS production and loss of viability upon acetic acid treatment and during early stationary phase. Moreover, cell death in aging yeast cells lacking PEX6 is not dependent on Mcalp and Aiflp and shows necrotic rather than apoptotic markers. The exact role of Pex6p in cells during acetic acid stress, as well in aging cells, remains to be clarified [150]. Interestingly, the deletion of the peroxisomal peroxiredoxin PMP2O gene in the yeast Hansenula polymorpha results in enhanced ROS production and accumulation of lipid peroxidation in methanol growing cells. Similar to the scenario observed in mitochondria-mediated apoptosis, the absence of Pmp20p leads to loss of peroxisome membrane integrity with the release of matrix proteins into the cytosol followed by necrotic cell death [151].

\section{Endoplasmic reticulum (ER)}

The yeast ER, as in all eukaryotes, is required for many relevant cellular functions such as the translocation and folding of proteins, the synthesis of lipids and the homeostasis of calcium.

In mammalian cells, loss of ER function leads to ER stress, which in turn can trigger endoplasmic reticulum stress-associated cell death (ER-SAD) [152]. Overload of proteins, exposure to long-chain saturated fatty acids, alterations in calcium levels and disturbances to the redox balance have been reported as the main factors leading to ER stress $[153,154]$. The unfolded protein response (UPR) is a signaling network comprising three or two pathways in animal and plant cells, respectively. The only UPR pathway in yeast is represented by inositol-requiring protein-1 (IRE1), complementary to IRE1 of plants where it plays an essential role in viral infection [155]. The UPR restores ER homeostasis by degrading misfolded proteins, by 
Fig. 1 Regulated cell death (RCD) scenarios in yeast at glance. Apoptotic-like and necrotic RCD are represented in red and black, respectively. External triggers, included in boxes shading from red to black, induce apoptotic $(\mathrm{red})$ or necrotic (black) RCD depending on their concentration

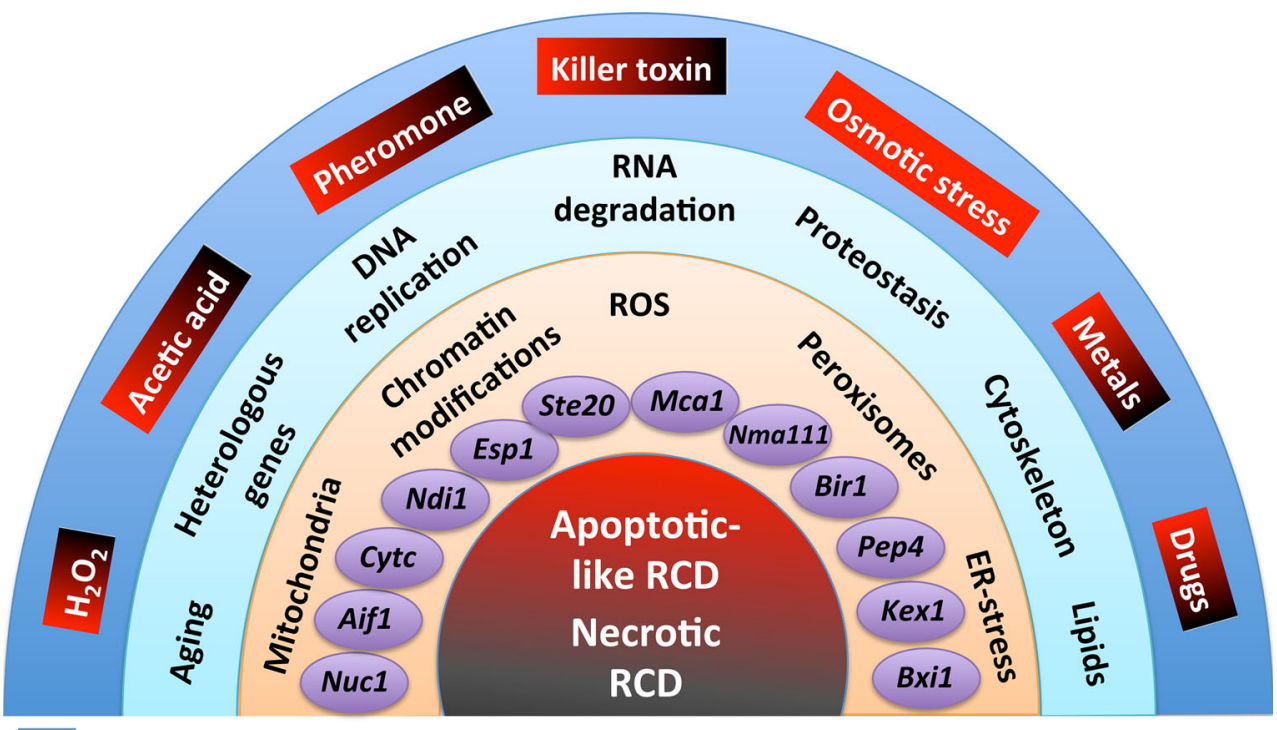

RCD external triggers

RCD Internal triggers

Pathways, organelles and molecules involved in RCD execution RCD executors increasing levels of chaperones to improve protein folding and by inhibiting translation. Failure of UPR activation leads cells to death. The overexpression of Yno1p, an NADPH oxidase localized in the perinuclear ER belonging to the NOX superfamily able to produce superoxide $\left(\mathrm{O}_{2} \cdot-\right)$, induces yeast cell death dependent on the presence of Mca1p [156].

\section{Conclusions and perspectives}

The current scenario of cell death has become more and more complex following the discovery of new forms of this process. The existence of the basal machinery of apoptosis, necrosis and apparently of autophagic cell death in yeast, makes this microorganism an easy model for the study of these phenomena. Figure 1 summarizes the actual scenario of regulated cell death.

Due to the easy manipulation by classical and molecular genetic approaches, yeast may be useful for the identification of new mammalian regulators and executors of cell death and, in the opposite direction, for the study of the effects of human genes in promoting or counteracting the different forms of RCD.

Finally, humanized yeast strains, expressing human genes not present in the yeast genome, constitute very powerful models for the study of aging, tumor progression, neurodegenerative disorders and for the development of new diagnostic assays and therapeutic molecules.

Open Access This article is distributed under the terms of the Creative Commons Attribution 4.0 International License (http:// creativecommons.org/licenses/by/4.0/), which permits unrestricted use, distribution, and reproduction in any medium, provided you give appropriate credit to the original author(s) and the source, provide a link to the Creative Commons license, and indicate if changes were made.

\section{References}

1. Galluzzi L, Vitale I, Abrams JM et al (2012) Molecular definitions of cell death subroutines: recommendations of the Nomenclature Committee on Cell Death 2012. Cell Death Differ 19:107-120. doi:10.1038/cdd.2011.96

2. Madeo F, Frohlich E, Frohlich KU (1997) A yeast mutant showing diagnostic markers of early and late apoptosis. J Cell Biol 139:729-734. doi:10.1083/jcb.139.3.729

3. Hirabayashi M, Inoue K, Tanaka K, Nakadate K, Ohsawa Y, Kamei Y, Popiel AH, Sinohara A, Iwamatsu A, Kimura Y, Uchiyama Y, Hori S, Kakizuka A (2001) VCP/p97 in abnormal protein aggregates, cytoplasmic vacuoles, and cell death, phenotypes relevant to neurodegeneration. Cell Death Differ 8:977-984. doi:10.1038/sj.cdd.4400907

4. Shirogane T, Fukada T, Muller JM, Shima DT, Hibi M, Hirano $\mathrm{T}$ (1999) Synergistic roles for Pim-1 and c-Myc in STAT3mediated cell cycle progression and antiapoptosis. Immunity 11:709-719. doi:10.1016/S1074-7613(00)80145-4

5. Lamb JR, Fu V, Wirtz E, Bangs JD (2001) Functional analysis of the trypanosomal AAA protein TbVCP with trans-dominant 
ATP hydrolysis mutants. J Biol Chem 276:21512-21520. doi:10.1074/jbc.M100235200

6. Higashiyama H, Hirose F, Yamaguchi M, Inoue YH, Fujikake N, Matsukage A, Kakizuka A (2002) Identification of ter94, Drosophila VCP, as a modulator of polyglutamine-induced neurodegeneration. Cell Death Differ 9:264-273. doi:10.1038/ $\mathrm{sj} / \mathrm{cdd} / 4400955$

7. Imamura S, Ojima N, Yamashita M (2003) Cold-inducible expression of the cell division cycle gene $\mathrm{CDC} 48$ and its promotion of cell proliferation during cold acclimation in zebrafish cells. FEBS Lett 549:14-20. doi:10.1016/S0014-5793(03)00723-3

8. Frohlich KU, Madeo F (2000) Apoptosis in yeast-a monocellular organism exhibits altruistic behaviour. FEBS Lett 473:6-9. doi:10.1016/S0014-5793(00)01474-5

9. Ludovico P, Sousa MJ, Silva MT, Leão C, Côrte-Real M (2001) Saccharomyces cerevisiae commits to a programmed cell death process in response to acetic acid. Microbiology 147:2409-2415. doi:10.1099/00221287-147-9-2409

10. Madeo F, Fröhlich E, Ligr M, Grey M, Sigrist SJ, Wolf DH, Fröhlich KU (1999) Oxygen stress: a regulator of apoptosis in yeast. J Cell Biol 145:757-767. doi:10.1083/jcb.145.4.757

11. Carmona-Gutierrez D, Eisenberg T, Buttner S, Meisinger C, Kroemer G, Madeo F (2010) Apoptosis in yeast: triggers, pathways, subroutines. Cell Death Differ 17(5):763-773. doi:10. 1038/cdd.2009.219

12. Liang Q, Zhou B (2007) Copper and manganese induce yeast apoptosis via different pathways. Mol Biol Cell 18:4741-4749. doi:10.1091/mbc.E07-05-0431

13. Carmona-Gutiérrez D, Bauer MA, Ring J, Knauer H, Eisenberg T, Büttner S, Ruckenstuhl C, Reisenbichler A, Magnes C, Rechberger GN, Birner-Gruenberger R, Jungwirth H, Fröhlich KU, Sinner F, Kroemer G, Madeo F (2011) The propeptide of yeast cathepsin D inhibits programmed necrosis. Cell Death Dis 19(2):e161. doi:10.1038/cddis.2011.43

14. Sheibani S, Richard VR, Beach A, Leonov A, Feldman R, Mattie S, Khelghatybana L, Piano A, Greenwood M, Vali H, Titorenko VI (2014) Macromitophagy, neutral lipids synthesis, and peroxisomal fatty acid oxidation protect yeast from "liponecrosis", a previously unknown form of programmed cell death. Cell Cycle 13:138-147. doi:10.4161/cc.26885

15. Richard VR, Beach A, Piano A, Leonov A, Feldman R, Burstein MT, Kyryakov P, Gomez-Perez A, Arlia-Ciommo A, Baptista S, Campbell C, Goncharov D, Pannu S, Patrinos D, Sadri B, Svistkova V, Victor A, Titorenko VI (2014) Mechanism of liponecrosis, a distinct mode of programmed cell death. Cell Cycle 13:3707-3726. doi:10.4161/15384101.2014.965003

16. Suzuki K (2013) Selective autophagy in budding yeast. Cell Death Differ 20:43-48. doi:10.1038/cdd.2012.73

17. Jin M, Klionsky DJ (2014) Regulation of autophagy: modulation of the size and number of autophagosomes. FEBS Lett 588:2457-2463. doi:10.1016/j.febslet.2014.06.015

18. Liu Y, Levine B (2015) Autosis and autophagic cell death: the dark side of autophagy. Cell Death Differ 22:367-376. doi:10. 1038/cdd.2014.143

19. Camougrand N, Kissova I, Velours G, Manon S (2004) Uth1p: a yeast mitochondrial protein at the crossroads of stress, degradation and cell death. FEMS Yeast Res 5:133-140. doi:10.1016/ j.femsyr.2004.05.001

20. Dziedzic SA, Caplan AB (2012) Autophagy proteins play cytoprotective and cytocidal roles in leucine starvation-induced cell death in Saccharomyces cerevisiae. Autophagy 8:731-738. doi:10.4161/auto.19314

21. Leão M, Gomes S, Bessa C, Soares J, Raimundo L, Monti P, Fronza G, Pereira C, Saraiva L (2015) Studying p53 family proteins in yeast: induction of autophagic cell death and modulation by interactors and small molecules. Exp Cell Res 330:164-177. doi:10.1016/j.yexcr.2014.09.028

22. Madeo F, Herker E, Maldener C, Wissing S, Lächelt S, Herlan M, Fehr M, Lauber K, Sigrist SJ, Wesselborg S, Fröhlich KU (2002) A caspase-related protease regulates apoptosis in yeast. Mol Cell 9:911-917. doi:10.1016/S1097-2765(02)00501-4

23. Tsiatsiani L, Van Breusegem F, Gallois P, Zavialov A, Lam E, Bozhkov PV (2011) Metacaspases. Cell Death Differ 18:1279-1288. doi:10.1038/cdd.2011.66

24. Wong AH, Yan C, Shi Y (2012) Crystal structure of the yeast metacaspase Yca1. J Biol Chem 287:29251-29259. doi:10.1074/ jbc.M112.381806

25. Watanabe N, Lam E (2005) Two Arabidopsis metacaspases AtMCP1b and AtMCP2b are arginine/lysine-specific cysteine proteases and activate apoptosis-like cell death in yeast. J Biol Chem 280:14691-14699. doi:10.1074/jbc.M413527200

26. Silva A, Almeida B, Sampaio-Marques B, Reis MI, Ohlmeier S, Rodrigues F, Vale A, Ludovico P (2011) Glyceraldehyde-3phosphate dehydrogenase (GAPDH) is a specific substrate of yeast metacaspase. Biochim Biophys Acta 1813:2044-2049. doi:10.1016/j.bbamcr.2011.09.010

27. Hill SM, Hao X, Liu B, Nystrom T (2014) Life-span extension by a metacaspase in the yeast Saccharomyces cerevisiae. Science 344:1389-1392. doi:10.1126/science.1252634

28. Hill SM, Nystrom T (2015) The dual role of a yeast metacaspase: what doesn't kill you makes you stronger. BioEssays 37:525-531. doi:10.1002/bies.201400208

29. Lee RE, Brunette S, Puente LG, Megeney LA (2010) Metacaspase Ycal is required for clearance of insoluble protein aggregates. Proc Natl Acad Sci USA 107:13348-13353. doi:10. 1073/pnas. 1006610107

30. Braun RJ, Zischka H, Madeo F, Eisenberg T, Wissing S, Buttner S, Engelhardt SM, Buringer D, Ueffing M (2006) Crucial mitochondrial impairment upon CDC48 mutation in apoptotic yeast. J Biol Chem 281:25757-25767. doi:10.1074/jbc.M513699200

31. Yang H, Ren Q, Zhang Z (2008) Cleavage of Mcd1 by caspaselike protease Esp1 promotes apoptosis in budding yeast. Mol Biol Cell 19:2127-2134. doi:10.1091/mbc.E07-11-1113

32. Hauptmann P, Lehle L (2008) Kex1 protease is involved in yeast cell death induced by defective $\mathrm{N}$-glycosylation, acetic acid, and chronological aging. J Biol Chem 283:19151-19163. doi:10. 1074/jbc.M801303200

33. Wissing S, Ludovico P, Herker E, Buttner S, Engelhardt SM, Decker T, Link A, Proksch A, Rodrigues F, Corte-Real M, Frohlich KU, Manns J, Cande C, Sigrist SJ, Kroemer G, Madeo F (2004) An AIF orthologue regulates apoptosis in yeast. J Cell Biol 166:969-974. doi:10.1083/jcb.200404138

34. Cande C, Vahsen N, Kouranti I, Schmitt E, Daugas E, Spahr C, Luban J, Kroemer RT, Giordanetto F, Garrido C, Penninger JM, Kroemer G (2004) AIF and cyclophilin A cooperate in apoptosis-associated chromatinolysis. Oncogene 23:1514-1521. doi:10.1038/sj.onc.1207279

35. Vahsen N, Cande C, Briere JJ, Benit P, Joza N, Larochette N, Mastroberardino PG, Pequignot MO, Casares N, Lazar V, Feraud O, Debili N, Wissing S, Engelhardt S, Madeo F, Piacentini M, Penninger JM, Schagger H, Rustin P, Kroemer G (2004) AIF deficiency compromises oxidative phosphorylation. EMBO J 23:4679-4689. doi:10.1038/sj.emboj.7600461

36. Li W, Sun L, Liang Q, Wang J, Mo W, Zhou B (2006) Yeast AMID homologue Ndilp displays respiration-restricted apoptotic activity and is involved in chronological aging. Mol Biol Cell 17:1802-1811. doi:10.1091/mbc.E05-04-0333

37. Buttner S, Eisenberg T, Carmona-Gutierrez D, Ruli D, Knauer H, Ruckenstuhl C, Sigrist C, Wissing S, Kollroser M, Frohlich KU, Sigrist S, Madeo F (2007) Endonuclease G regulates 
budding yeast life and death. Mol Cell 25:233-246. doi:10.1016/ j.molcel.2006.12.021

38. Buttner S, Carmona-Gutierrez D, Vitale I, Castedo M, Ruli D, Eisenberg T, Kroemer G, Madeo F (2007) Depletion of endonuclease $\mathrm{G}$ selectively kills polyploid cells. Cell Cycle 6:1072-1076. doi:10.4161/cc.6.9.4218

39. Fahrenkrog B, Sauder U, Aebi U (2004) The S. cerevisiae HtrAlike protein Nma111p is a nuclear serine protease that mediates yeast apoptosis. J Cell Sci 117:115-126. doi:10.1242/jcs.00848

40. Walter D, Wissing S, Madeo F, Fahrenkrog B (2006) The inhibitor-of-apoptosis protein Birlp protects against apoptosis in S. cerevisiae and is a substrate for the yeast homologue of Omi/ HtrA2. J Cell Sci 119:1843-1851. doi:10.1242/jcs.02902

41. Mason DA, Shulga N, Undavai S, Ferrando-May E, Rexach MF, Goldfarb DS (2005) Increased nuclear envelope permeability and Pep4p-dependent degradation of nucleoporins during hydrogen peroxide-induced cell death. FEMS Yeast Res 5:1237-1251. doi:10.1016/j.femsyr.2005.07.008

42. Oliveira CS, Pereira H, Alves S, Castro L, Baltazar F, Chaves SR, Preto A, Corte-Real M (2015) Cathepsin D protects colorectal cancer cells from acetate-induced apoptosis through autophagy-independent degradation of damaged mitochondria. Cell Death Dis 6:e1788. doi:10.1038/cddis.2015.157

43. Pereira C, Chaves S, Alves S, Salin B, Camougrand N, Manon S, Sousa MJ, Corte-Real M (2010) Mitochondrial degradation in acetic acid-induced yeast apoptosis: the role of Pep4 and the ADP/ATP carrier. Mol Microbiol 76:1398-1410. doi:10.1111/j. 1365-2958.2010.07122.x

44. Antignani A, Youle RJ (2006) How do Bax and Bak lead to permeabilization of the outer mitochondrial membrane? Curr Opin Cell Biol 18:685-689. doi:10.1016/j.ceb.2006.10.004

45. Green DR, Kroemer G (2004) The pathophysiology of mitochondrial cell death. Science 305:626-629. doi:10.1126/science. 1099320

46. Buttner S, Ruli D, Vogtle FN, Galluzzi L, Moitzi B, Eisenberg T, Kepp O, Habernig L, Carmona-Gutierrez D, Rockenfeller P, Laun P, Breitenbach M, Khoury C, Frohlich KU, Rechberger G, Meisinger C, Kroemer G, Madeo F (2011) A yeast BH3-only protein mediates the mitochondrial pathway of apoptosis. EMBO J 30(14):2779-2792. doi:10.1038/emboj.2011.197

47. Cebulski J, Malouin J, Pinches N, Cascio V, Austriaco N (2011) Yeast Bax inhibitor, Bxilp, is an ER-localized protein that links the unfolded protein response and programmed cell death in Saccharomyces cerevisiae. PLoS One 6:e20882. doi:10.1371/ journal.pone. 0020882

48. Bettiga M, Calzari L, Orlandi I, Alberghina L, Vai M (2004) Involvement of the yeast metacaspase Yca1 in ubp10Deltaprogrammed cell death. FEMS Yeast Res 5:141-147. doi:10. 1016/j.femsyr.2004.07.005

49. Hauptmann P, Riel C, Kunz-Schughart LA, Frohlich KU, Madeo F, Lehle L (2006) Defects in N-glycosylation induce apoptosis in yeast. Mol Microbiol 59:765-778. doi:10.1111/j. 1365-2958.2005.04981.x

50. Leadsham JE, Kotiadis VN, Tarrant DJ, Gourlay CW (2009) Apoptosis and the yeast actin cytoskeleton. Cell Death Differ 17(5):754-762. doi:10.1038/cdd.2009.196

51. Mazzoni C, Mancini P, Verdone L, Madeo F, Serafini A, Herker E, Falcone C (2003) A truncated form of KlLsm4p and the absence of factors involved in mRNA decapping trigger apoptosis in yeast. Mol Biol Cell 14:721-729. doi:10.1091/mbc.E0205-0258

52. Smethurst DG, Dawes IW, Gourlay CW (2014) Actin-a biosensor that determines cell fate in yeasts. FEMS Yeast Res 14:89-95. doi:10.1111/1567-1364.12119

53. Weinberger M, Ramachandran L, Feng L, Sharma K, Sun X, Marchetti M, Huberman JA, Burhans WC (2005) Apoptosis in budding yeast caused by defects in initiation of DNA replication. J Cell Sci 118:3543-3553. doi:10.1242/jcs.02477

54. Longo VD, Gralla EB, Valentine JS (1996) Superoxide dismutase activity is essential for stationary phase survival in Saccharomyces cerevisiae. Mitochondrial production of toxic oxygen species in vivo. J Biol Chem 271:12275-12280

55. Ayer A, Gourlay CW, Dawes IW (2014) Cellular redox homeostasis, reactive oxygen species and replicative ageing in Saccharomyces cerevisiae. FEMS Yeast Res 14:60-72. doi:10. 1111/1567-1364.12114

56. Perrone GG, Tan SX, Dawes IW (2008) Reactive oxygen species and yeast apoptosis. Biochim Biophys Acta 1783:1354-1368. doi:10.1016/j.bbamcr.2008.01.023

57. Farrugia G, Balzan R (2012) Oxidative stress and programmed cell death in yeast. Front Oncol 2:64. doi:10.3389/fonc.2012. 00064

58. Fabrizio P, Pletcher SD, Minois N, Vaupel JW, Longo VD (2004) Chronological aging-independent replicative life span regulation by Msn2/Msn4 and Sod2 in Saccharomyces cerevisiae. FEBS Lett 557:136-142. doi:10.1016/S00145793(03)01462-5

59. Herker E, Jungwirth H, Lehmann KA, Maldener C, Frohlich KU, Wissing S, Buttner S, Fehr M, Sigrist S, Madeo F (2004) Chronological aging leads to apoptosis in yeast. J Cell Biol 164:501-507. doi:10.1083/jcb.200310014

60. Laun P, Pichova A, Madeo F, Fuchs J, Ellinger A, Kohlwein S, Dawes I, Frohlich KU, Breitenbach M (2001) Aged mother cells of Saccharomyces cerevisiae show markers of oxidative stress and apoptosis. Mol Microbiol 39:1166-1173. doi:10.1046/j. 1365-2958.2001.02317.x

61. Diffley JF (2001) DNA replication: building the perfect switch. Curr Biol 11:R367-R370. doi:10.1016/S0960-9822(01)00196-8

62. Burhans WC, Weinberger M (2012) DNA damage and DNA replication stress in yeast models of aging. Subcell Biochem 57:187-206. doi:10.1007/978-94-007-2561-4_9

63. Blanchard F, Rusiniak ME, Sharma K, Sun X, Todorov I, Castellano MM, Gutierrez C, Baumann H, Burhans WC (2002) Targeted destruction of DNA replication protein Cdc6 by cell death pathways in mammals and yeast. Mol Biol Cell 13:1536-1549. doi:10.1091/mbc.02-02-0010

64. Braun KA, Young ET (2014) Coupling mRNA synthesis and decay. Mol Cell Biol 34:4078-4087. doi:10.1128/MCB.0053514

65. Mazzoni C, Mancini P, Madeo F, Palermo V, Falcone C (2003) A Kluyveromyces lactis mutant in the essential gene KILSM4 shows phenotypic markers of apoptosis. FEMS Yeast Res 4:29-35. doi:10.1016/S1567-1356(03)00151-X

66. Mazzoni C, Herker E, Palermo V, Jungwirth H, Eisenberg T, Madeo F, Falcone C (2005) Yeast caspase 1 links messenger RNA stability to apoptosis in yeast. EMBO Rep 6:1076-1081. doi:10.1038/sj.embor.7400514

67. Mazzoni C, Palermo V, Torella M, Falcone C (2005) HIR1, the co-repressor of histone gene transcription of Saccharomyces cerevisiae, acts as a multicopy suppressor of the apoptotic phenotypes of the LSM4 mRNA degradation mutant. FEMS Yeast Res 5:1229-1235. doi:10.1016/j.femsyr.2005.07.007

68. Mazzoni C, Torella M, Petrera A, Palermo V, Falcone C (2009) PGK1, the gene encoding the glycolytic enzyme phosphoglycerate kinase, acts as a multicopy suppressor of apoptotic phenotypes in $S$. cerevisiae. Yeast 26:31-37. doi:10.1002/yea.1647

69. Palermo V, Stirpe M, Torella M, Falcone C, Mazzoni C (2015) NEM1 acts as a suppressor of apoptotic phenotypes in LSM4 yeast mutants. FEMS Yeast Res 15(7):fov074. doi:10.1093/ femsyr/fov074

70. Raju KK, Natarajan S, Kumar NS, Kumar DA, Raghavendra NM (2015) Role of cytoplasmic deadenylation and mRNA 
decay factors in yeast apoptosis. FEMS Yeast Res 15(2):fou006. doi:10.1093/femsyr/fou006

71. Del Prete MJ, Robles MS, Guao A, Martinez-A C, Izquierdo M, Garcia-Sanz JA (2002) Degradation of cellular mRNA is a general early apoptosis-induced event. FASEB J 16:2003-2005. doi:10.1096/fj.02-0392fje

72. Thomas MP, Liu X, Whangbo J, McCrossan G, Sanborn KB, Basar E, Walch M, Lieberman J (2015) Apoptosis triggers specific, rapid, and global mRNA decay with $3^{\prime}$ uridylated intermediates degraded by DIS3L2. Cell Rep 11:1079-1089. doi:10.1016/j.celrep.2015.04.026

73. Rissland OS, Norbury CJ (2009) Decapping is preceded by $3^{\prime}$ uridylation in a novel pathway of bulk mRNA turnover. Nat Struct Mol Biol 16:616-623. doi:10.1038/nsmb.1601

74. Mroczek S, Kufel J (2008) Apoptotic signals induce specific degradation of ribosomal RNA in yeast. Nucleic Acids Res 36:2874-2888. doi:10.1093/nar/gkm1100

75. Thompson DM, Parker R (2009) The RNase Rnylp cleaves tRNAs and promotes cell death during oxidative stress in Saccharomyces cerevisiae. J Cell Biol 185(1):43-50. doi:10.1083/ jcb.200811119

76. Fullgrabe J, Hajji N, Joseph B (2010) Cracking the death code: apoptosis-related histone modifications. Cell Death Differ 17:1238-1243. doi:10.1038/cdd.2010.58

77. Ahn SH, Cheung WL, Hsu JY, Diaz RL, Smith MM, Allis CD (2005) Sterile 20 kinase phosphorylates histone H2B at serine 10 during hydrogen peroxide-induced apoptosis in $S$. cerevisiae. Cell 120:25-36. doi:10.1016/j.cell.2004.11.016

78. Ahn SH, Diaz RL, Grunstein M, Allis CD (2006) Histone H2B deacetylation at lysine 11 is required for yeast apoptosis induced by phosphorylation of H2B at serine 10. Mol Cell 24:211-220. doi:10.1016/j.molcel.2006.09.008

79. Ahn SH, Henderson KA, Keeney S, Allis CD (2005) H2B (Ser10) phosphorylation is induced during apoptosis and meiosis in S. cerevisiae. Cell Cycle 4:780-783

80. Orlandi I, Bettiga M, Alberghina L, Vai M (2004) Transcriptional profiling of ubp10 null mutant reveals altered subtelomeric gene expression and insurgence of oxidative stress response. J Biol Chem 279:6414-6425. doi:10.1074/jbc.M306464200

81. Walter D, Matter A, Fahrenkrog B (2010) Bre1p-mediated histone H2B ubiquitylation regulates apoptosis in Saccharomyces cerevisiae. J Cell Sci 123:1931-1939. doi:10.1242/jcs.065938

82. Walter D, Matter A, Fahrenkrog B (2014) Loss of histone H3 methylation at lysine 4 triggers apoptosis in Saccharomyces cerevisiae. PLoS Genet 10:e1004095. doi:10.1371/journal.pgen. 1004095

83. Vachova L, Palkova Z (2005) Physiological regulation of yeast cell death in multicellular colonies is triggered by ammonia. J Cell Biol 169:711-717. doi:10.1083/jcb.200410064

84. Clapp C, Portt L, Khoury C, Sheibani S, Norman G, Ebner P, Eid R, Vali H, Mandato CA, Madeo F, Greenwood MT (2012) 14-3-3 protects against stress-induced apoptosis. Cell Death Dis 3:e348. doi:10.1038/cddis.2012.90

85. Clapp C, Portt L, Khoury C, Sheibani S, Eid R, Greenwood M, Vali H, Mandato CA, Greenwood MT (2012) Untangling the roles of anti-apoptosis in regulating programmed cell death using humanized yeast cells. Front Oncol 2:59. doi:10.3389/ fonc. 2012.00059

86. Sheibani S, Jones NK, Eid R, Gharib N, Arab NT, Titorenko V, Vali H, Young PA, Greenwood MT (2015) Inhibition of stress mediated cell death by human lactate dehydrogenase B in yeast. FEMS Yeast Res 15(5):fov032. doi:10.1093/femsyr/fov032

87. Braun RJ (2015) Ubiquitin-dependent proteolysis in yeast cells expressing neurotoxic proteins. Front Mol Neurosci 8:8. doi:10. 3389/fnmol.2015.00008
88. Buttner S, Bitto A, Ring J, Augsten M, Zabrocki P, Eisenberg T, Jungwirth $\mathrm{H}$, Hutter S, Carmona-Gutierrez D, Kroemer G, Winderickx J, Madeo F (2008) Functional mitochondria are required for alpha-synuclein toxicity in ageing yeast. J Biol Chem 283(12):7554-7560. doi:10.1074/jbc.M708477200

89. Sampaio-Marques B, Felgueiras C, Silva A, Rodrigues M, Tenreiro S, Franssens V, Reichert AS, Outeiro TF, Winderickx J, Ludovico P (2012) SNCA (alpha-synuclein)-induced toxicity in yeast cells is dependent on sirtuin 2 (Sir2)-mediated mitophagy. Autophagy 8:1494-1509. doi:10.4161/auto.21275

90. Buttner S, Habernig L, Broeskamp F, Ruli D, Vogtle FN, Vlachos M, Macchi F, Kuttner V, Carmona-Gutierrez D, Eisenberg T, Ring J, Markaki M, Taskin AA, Benke S, Ruckenstuhl C, Braun R, Van den Haute C, Bammens T, van der Perren A, Frohlich KU, Winderickx J, Kroemer G, Baekelandt V, Tavernarakis N, Kovacs GG, Dengjel J, Meisinger C, Sigrist SJ, Madeo F (2013) Endonuclease G mediates alpha-synuclein cytotoxicity during Parkinson's disease. EMBO J 32:3041-3054. doi:10.1038/emboj.2013.228

91. Bocharova NA, Sokolov SS, Knorre DA, Skulachev VP, Severin FF (2008) Unexpected link between anaphase promoting complex and the toxicity of expanded polyglutamines expressed in yeast. Cell Cycle 7:3943-3946. doi:10.4161/cc.7.24.7398

92. Sokolov S, Pozniakovsky A, Bocharova N, Knorre D, Severin F (2006) Expression of an expanded polyglutamine domain in yeast causes death with apoptotic markers. Biochim Biophys Acta 1757:660-666. doi:10.1016/j.bbabio.2006.05.004

93. Kawaguchi Y, Okamoto T, Taniwaki M, Aizawa M, Inoue M, Katayama S, Kawakami H, Nakamura S, Nishimura M, Akiguchi I et al (1994) CAG expansions in a novel gene for Machado-Joseph disease at chromosome 14q32.1. Nat Genet 8:221-228. doi:10.1038/ng1194-221

94. Bonanomi M, Visentin C, Invernizzi G, Tortora P, Regonesi ME (2015) The toxic effects of pathogenic ataxin-3 variants in a yeast cellular model. PLoS One 10:e0129727. doi:10.1371/ journal.pone. 0129727

95. Van Rossom S, Op de Beeck K, Franssens V, Swinnen E, Schepers A, Ghillebert R, Caldara M, Van Camp G, Winderickx J (2012) The splicing mutant of the human tumor suppressor protein DFNA5 induces programmed cell death when expressed in the yeast Saccharomyces cerevisiae. Front Oncol 2:77. doi:10.3389/fonc. 2012.00077

96. Van Rossom S, Op de Beeck K, Hristovska V, Winderickx J, Van Camp G (2015) The deafness gene DFNA5 induces programmed cell death through mitochondria and MAPK-related pathways. Front Cell Neurosci 9:231. doi:10.3389/fncel.2015. 00231

97. Blanco R, Carrasco L, Ventoso I (2003) Cell killing by HIV-1 protease. J Biol Chem 278:1086-1093. doi:10.1074/jbc. M205636200

98. Sripriya P, Vedantam LV, Podile AR (2009) Involvement of mitochondria and metacaspase elevation in harpin Pss-induced cell death of Saccharomyces cerevisiae. J Cell Biochem 107:1150-1159. doi:10.1002/jcb.22217

99. Meek DW (2015) Regulation of the p53 response and its relationship to cancer. Biochem J 469:325-346. doi:10.1042/ BJ20150517

100. Scharer E, Iggo R (1992) Mammalian p53 can function as a transcription factor in yeast. Nucleic Acids Res 20:1539-1545. doi:10.1093/nar/20.7.1539

101. Guaragnella N, Palermo V, Galli A, Moro L, Mazzoni C, Giannattasio S (2014) The expanding role of yeast in cancer research and diagnosis: insights into the function of the oncosuppressors p53 and BRCA1/2. FEMS Yeast Res 14:2-16. doi:10.1111/1567-1364.12094 
102. Hadj Amor IY, Smaoui K, Chaabene I, Mabrouk I, Djemal L, Elleuch H, Allouche M, Mokdad-Gargouri R, Gargouri A (2008) Human p53 induces cell death and downregulates thioredoxin expression in Saccharomyces cerevisiae. FEMS Yeast Res 8:1254-1262. doi:10.1111/j.1567-1364.2008.00445.x

103. Mokdad-Gargouri R, Belhadj K, Gargouri A (2001) Translational control of human p53 expression in yeast mediated by $5^{\prime}$ UTR-ORF structural interaction. Nucleic Acids Res 29:1222-1227. doi:10.1093/nar/29.5.1222

104. Muscolini M, Montagni E, Palermo V, Di Agostino S, Gu W, Abdelmoula-Souissi S, Mazzoni C, Blandino G, Tuosto L (2011) The cancer-associated K351N mutation affects the ubiquitination and the translocation to mitochondria of p53 protein. J Biol Chem 286:39693-39702. doi:10.1074/jbc.M111. 279539

105. Palermo V, Mangiapelo E, Piloto C, Pieri L, Muscolini M, Tuosto L, Mazzoni C (2013) p53 death signal is mainly mediated by Nuc1(EndoG) in the yeast Saccharomyces cerevisiae. FEMS Yeast Res 13:682-688. doi:10.1111/1567-1364.12067

106. Guaragnella N, Marra E, Galli A, Moro L, Giannattasio S (2014) Silencing of BRCA2 decreases anoikis and its heterologous expression sensitizes yeast cells to acetic acid-induced programmed cell death. Apoptosis 19:1330-1341. doi:10.1007/ s10495-014-1006-z

107. Giannattasio S, Guaragnella N, Zdralevic M, Marra E (2013) Molecular mechanisms of Saccharomyces cerevisiae stress adaptation and programmed cell death in response to acetic acid. Front Microbiol 4:33. doi:10.3389/fmicb.2013.00033

108. Pereira C, Silva RD, Saraiva L, Johansson B, Sousa MJ, CorteReal M (2008) Mitochondria-dependent apoptosis in yeast. Biochim Biophys Acta 1783:1286-1302. doi:10.1016/j.bbamcr. 2008.03.010

109. Giannattasio S, Atlante A, Antonacci L, Guaragnella N, Lattanzio P, Passarella S, Marra E (2008) Cytochrome $c$ is released from coupled mitochondria of yeast en route to acetic acidinduced programmed cell death and can work as an electron donor and a ROS scavenger. FEBS Lett 582:1519-1525. doi:10. 1016/j.febslet.2008.03.048

110. Ludovico P, Rodrigues F, Almeida A, Silva MT, Barrientos A, Corte-Real M (2002) Cytochrome $c$ release and mitochondria involvement in programmed cell death induced by acetic acid in Saccharomyces cerevisiae. Mol Biol Cell 13:2598-2606. doi:10. 1091/mbc.E01-12-0161

111. Guaragnella N, Passarella S, Marra E, Giannattasio S (2010) Knock-out of metacaspase and/or cytochrome $c$ results in the activation of a ROS-independent acetic acid-induced programmed cell death pathway in yeast. FEBS Lett 584:3655-3660. doi:10.1016/j.febslet.2010.07.044

112. Guaragnella N, Bobba A, Passarella S, Marra E, Giannattasio S (2010) Yeast acetic acid-induced programmed cell death can occur without cytochrome $c$ release which requires metacaspase YCA1. FEBS Lett 584:224-228. doi:10.1016/j.febslet.2009.11. 072

113. Pereira C, Camougrand N, Manon S, Sousa MJ, Corte-Real M (2007) ADP/ATP carrier is required for mitochondrial outer membrane permeabilization and cytochrome $c$ release in yeast apoptosis. Mol Microbiol 66:571-582. doi:10.1111/j.1365-2958. 2007.05926.x

114. Fannjiang Y, Cheng WC, Lee SJ, Qi B, Pevsner J, McCaffery JM, Hill RB, Basanez G, Hardwick JM (2004) Mitochondrial fission proteins regulate programmed cell death in yeast. Genes Dev 18:2785-2797. doi:10.1101/gad.1247904

115. Rego A, Duarte AM, Azevedo F, Sousa MJ, Corte-Real M, Chaves SR (2014) Cell wall dynamics modulate acetic acidinduced apoptotic cell death of Saccharomyces cerevisiae. Microbial Cell 1:303-314
116. Longo V, Zdralevic M, Guaragnella N, Giannattasio S, Zolla L, Timperio AM (2015) Proteome and metabolome profiling of wild-type and YCA1-knock-out yeast cells during acetic acidinduced programmed cell death. J Proteomics 128:173-188. doi:10.1016/j.jprot.2015.08.003

117. Brocker C, Thompson DC, Vasiliou V (2012) The role of hyperosmotic stress in inflammation and disease. Biomol Concepts 3:345-364. doi:10.1515/bmc-2012-0001

118. Watanabe T, Srichuwong S, Arakane M, Tamiya S, Yoshinaga M, Watanabe I, Yamamoto M, Ando A, Tokuyasu K, Nakamura $\mathrm{T}$ (2010) Selection of stress-tolerant yeasts for simultaneous saccharification and fermentation (SSF) of very high gravity (VHG) potato mash to ethanol. Bioresour Technol 101:9710-9714. doi:10.1016/j.biortech.2010.07.07

119. Saito H, Posas F (2012) Response to hyperosmotic stress. Genetics 192:289-318. doi:10.1534/genetics.112.140863

120. Silva RD, Sotoca R, Johansson B, Ludovico P, Sansonetty F, Silva MT, Peinado JM, Corte-Real M (2005) Hyperosmotic stress induces metacaspase- and mitochondria-dependent apoptosis in Saccharomyces cerevisiae. Mol Microbiol 58:824-834. doi:10.1111/j.1365-2958.2005.04868.x

121. Huh GH, Damsz B, Matsumoto TK, Reddy MP, Rus AM, Ibeas JI, Narasimhan ML, Bressan RA, Hasegawa PM (2002) Salt causes ion disequilibrium-induced programmed cell death in yeast and plants. Plant J 29:649-659. doi:10.1046/j.0960-7412. 2001.01247.x

122. Wadskog I, Maldener C, Proksch A, Madeo F, Adler L (2004) Yeast lacking the SRO7/SOP1-encoded tumor suppressor homologue show increased susceptibility to apoptosis-like cell death on exposure to $\mathrm{NaCl}$ stress. Mol Biol Cell 15:1436-1444. doi:10.1091/mbc.E03-02-0114

123. Schmitt MJ, Reiter J (2008) Viral induced yeast apoptosis. Biochim Biophys Acta 1783:1413-1417. doi:10.1016/j.bbamcr. 2008.01.017

124. Reiter J, Herker E, Madeo F, Schmitt MJ (2005) Viral killer toxins induce caspase-mediated apoptosis in yeast. J Cell Biol 168:353-358. doi:10.1083/jcb.200408071

125. Severin FF, Hyman AA (2002) Pheromone induces programmed cell death in S. cerevisiae. Curr Biol 12:R233-R235. doi:10. 1016/S0960-9822(02)00776-5

126. Pozniakovsky AI, Knorre DA, Markova OV, Hyman AA, Skulachev VP, Severin FF (2005) Role of mitochondria in the pheromone- and amiodarone-induced programmed death of yeast. J Cell Biol 168:257-269. doi:10.1083/jcb.200408145

127. Botstein D, Fink GR (2011) Yeast: an experimental organism for 21st century biology. Genetics 189:695-704. doi:10.1534/ genetics.111.130765

128. Almeida B, Silva A, Mesquita A, Sampaio-Marques B, Rodrigues F, Ludovico P (2008) Drug-induced apoptosis in yeast. Biochim Biophys Acta 1783:1436-1448. doi:10.1016/j.bbamcr. 2008.01.005

129. La Regina G, Sarkar T, Bai R, Edler MC, Saletti R, Coluccia A, Piscitelli F, Minelli L, Gatti V, Mazzoccoli C, Palermo V, Mazzoni C, Falcone C, Scovassi AI, Giansanti V, Campiglia P, Porta A, Maresca B, Hamel E, Brancale A, Novellino E, Silvestri R (2009) New arylthioindoles and related bioisosteres at the sulfur bridging group. 4. Synthesis, tubulin polymerization, cell growth inhibition, and molecular modeling studies. J Med Chem 52:7512-7527. doi:10.1021/jm900016t

130. Palermo V, Pieri L, Silvestri R, La Regina G, Falcone C, Mazzoni C (2011) Drug-induced inhibition of tubulin polymerization induces mitochondrion-mediated apoptosis in yeast. Cell Cycle 10:3208-3209. doi:10.4161/cc.10.18.16514

131. Rockenfeller P, Ring J, Muschett V, Beranek A, Buettner S, Carmona-Gutierrez D, Eisenberg T, Khoury C, Rechberger G, Kohlwein SD, Kroemer G, Madeo F (2010) Fatty acids trigger 
mitochondrion-dependent necrosis. Cell Cycle 9(14):28362842. doi:10.4161/cc.9.14.12346

132. Cassidy-Stone A, Chipuk JE, Ingerman E, Song C, Yoo C, Kuwana T, Kurth MJ, Shaw JT, Hinshaw JE, Green DR, Nunnari $\mathrm{J}$ (2008) Chemical inhibition of the mitochondrial division dynamin reveals its role in Bax/Bak-dependent mitochondrial outer membrane permeabilization. Dev Cell 14:193-204

133. Palermo V, Falcone C, Calvani M, Mazzoni C (2010) Acetyl-Lcarnitine protects yeast cells from apoptosis and aging and inhibits mitochondrial fission. Aging Cell 9:570-579. doi:10. 1111/j.1474-9726.2010.00587.x

134. Amari F, Fettouche A, Samra MA, Kefalas P, Kampranis SC, Makris AM (2008) Antioxidant small molecules confer variable protection against oxidative damage in yeast mutants. J Agric Food Chem 56:11740-11751

135. Palermo V, Mattivi F, Silvestri R, La Regina G, Falcone C, Mazzoni C (2012) Apple can act as anti-aging on yeast cells. Oxid Med Cell Longev 2012:491759. doi:10.1155/2012/491759

136. Morselli E, Marino G, Bennetzen MV, Eisenberg T, Megalou E, Schroeder S, Cabrera S, Benit P, Rustin P, Criollo A, Kepp O, Galluzzi L, Shen S, Malik SA, Maiuri MC, Horio Y, Lopez-Otin C, Andersen JS, Tavernarakis N, Madeo F, Kroemer G (2011) Spermidine and resveratrol induce autophagy by distinct pathways converging on the acetylproteome. J Cell Biol 192:615-629. doi:10.1083/jcb.201008167

137. Eisenberg T, Knauer H, Schauer A, Buttner S, Ruckenstuhl C, Carmona-Gutierrez D, Ring J, Schroeder S, Magnes C, Antonacci L, Fussi H, Deszcz L, Hartl R, Schraml E, Criollo A, Megalou E, Weiskopf D, Laun P, Heeren G, Breitenbach M, Grubeck-Loebenstein B, Herker E, Fahrenkrog B, Frohlich KU, Sinner F, Tavernarakis N, Minois N, Kroemer G, Madeo F (2009) Induction of autophagy by spermidine promotes longevity. Nat Cell Biol 11:1305-1314. doi:10.1038/ncb1975

138. Suen DF, Norris KL, Youle RJ (2008) Mitochondrial dynamics and apoptosis. Genes Dev 22:1577-1590. doi:10.1101/gad. 1658508

139. Manon S, Chaudhuri B, Guerin M (1997) Release of cytochrome $c$ and decrease of cytochrome $c$ oxidase in Bax-expressing yeast cells, and prevention of these effects by coexpression of Bcl-xL. FEBS Lett 415:29-32. doi:10.1016/S0014-5793(97)01087-9

140. Gross A, Pilcher K, Blachly-Dyson E, Basso E, Jockel J, Bassik MC, Korsmeyer SJ, Forte M (2000) Biochemical and genetic analysis of the mitochondrial response of yeast to BAX and BCL-X(L). Mol Cell Biol 20:3125-3136. doi:10.1128/MCB.20. 9.3125-3136.2000

141. Kissova I, Polcic P, Kempna P, Zeman I, Sabova L, Kolarov J (2000) The cytotoxic action of Bax on yeast cells does not require mitochondrial $\mathrm{ADP} / \mathrm{ATP}$ carrier but may be related to its import to the mitochondria. FEBS Lett 471:113-118. doi:10. 1016/S0014-5793(00)01379-X

142. Shimizu S, Narita M, Tsujimoto Y (1999) Bcl-2 family proteins regulate the release of apoptogenic cytochrome $c$ by the mitochondrial channel VDAC. Nature 399:483-487. doi:10.1038/ 35037638

143. De Pinto V, Guarino F, Guarnera A, Messina A, Reina S, Tomasello FM, Palermo V, Mazzoni C (2010) Characterization of human VDAC isoforms: a peculiar function for VDAC3? Biochim Biophys Acta 1797:1268-1275. doi:10.1016/j.bbabio. 2010.01.031

144. Kirchman PA, Kim S, Lai CY, Jazwinski SM (1999) Interorganelle signaling is a determinant of longevity in Saccharomyces cerevisiae. Genetics 152:179-190

145. Cerveny KL, Tamura Y, Zhang Z, Jensen RE, Sesaki H (2007) Regulation of mitochondrial fusion and division. Trends Cell Biol 17:563-569. doi:10.1016/j.tcb.2007.08.006

146. Palermo V, Falcone C, Mazzoni C (2007) Apoptosis and aging in mitochondrial morphology mutants of $S$. cerevisiae. Folia Microbiol (Praha) 52:479-483. doi:10.1007/BF02932107

147. Scheckhuber CQ, Erjavec N, Tinazli A, Hamann A, Nystrom T, Osiewacz HD (2007) Reducing mitochondrial fission results in increased life span and fitness of two fungal ageing models. Nat Cell Biol 9:99-105. doi:10.1038/ncb1524

148. Almeida T, Marques M, Mojzita D, Amorim MA, Silva RD, Almeida B, Rodrigues P, Ludovico P, Hohmann S, MoradasFerreira P, Corte-Real M, Costa V (2008) Isc1p plays a key role in hydrogen peroxide resistance and chronological lifespan through modulation of iron levels and apoptosis. Mol Biol Cell 19:865-876. doi:10.1091/mbc.E07-06-0604

149. Lefevre SD, Kumar S, van der Klei IJ (2015) Inhibition of peroxisome fission, but not mitochondrial fission, increases yeast chronological lifespan. Cell Cycle 14:1698-1703. doi:10. 1080/15384101.2015.1029685

150. Jungwirth H, Ring J, Mayer T, Schauer A, Buttner S, Eisenberg T, Carmona-Gutierrez D, Kuchler K, Madeo F (2008) Loss of peroxisome function triggers necrosis. FEBS Lett 582:28822886. doi:10.1016/j.febslet.2008.07.023

151. Eisenberg T, Carmona-Gutierrez D, Buttner S, Tavernarakis N, Madeo F (2010) Necrosis in yeast. Apoptosis 15(3):257-268. doi:10.1007/s10495-009-0453-4

152. Austriaco N (2012) Endoplasmic reticulum involvement in yeast cell death. Front Oncol 2:87. doi:10.3389/fonc.2012.00087. eCollection

153. Parmar VM, Schroder M (2012) Sensing endoplasmic reticulum stress. Adv Exp Med Biol 738:153-168. doi:10.1007/978-14614-1680-7 10

154. Ron D, Walter P (2007) Signal integration in the endoplasmic reticulum unfolded protein response. Nat Rev Mol Cell Biol 8:519-529. doi:10.1038/nrm2199

155. Zhang L, Chen H, Brandizzi F, Verchot J, Wang A (2015) The UPR branch IRE1-bZIP60 in plants plays an essential role in viral infection and is complementary to the only UPR pathway in yeast. PLoS Genet 11:e1005164. doi:10.1371/journal.pgen. 1005164.eCollection

156. Rinnerthaler M, Buttner S, Laun P, Heeren G, Felder TK, Klinger H, Weinberger M, Stolze K, Grousl T, Hasek J, Benada O, Frydlova I, Klocker A, Simon-Nobbe B, Jansko B, Breitenbach-Koller H, Eisenberg T, Gourlay CW, Madeo F, Burhans WC, Breitenbach M (2012) Yno1p/Aim14p, a NADPH-oxidase ortholog, controls extramitochondrial reactive oxygen species generation, apoptosis, and actin cable formation in yeast. Proc Natl Acad Sci USA 109:8658-8663. doi:10.1073/pnas. 1201629109 (Epub 2012 May 14) 